\title{
İslâmî Kaynaklarda ve Oryantalist Metinlerde Besmeleye Yaklaşımlar
}

\section{Approaches to Basmala in Islamic Sources and Orientalist Texts}

\section{İshak Kızılaslan}

Öğr. Gör. Dr., Marmara Üniversitesi, İlahiyat Fakültesi, Kur'an-ı Kerim Okuma ve Kıraat Ilmi Anabilim Dalı Lecturer PhD., Marmara University, Faculty of Theology, Department of Quran Reading and Recitation Science Istanbul, Turkey ishakkizilaslan@yahoo.com | https://orcid.org/0000-0001-5272-1078

\section{Article Type / Makale Tipi \\ Research Article / Araştırma Makalesi}

DOI: $10.33420 /$ marife.913335
Article Information / Makale Bilgisi

Received / Geliş Tarihi: 11.04.2021

Accepted / Kabul Tarihi: 25.05.2021

Published / Yayın Tarihi: 30.06.2021

Cite as / Atıf: Kızılaslan, İshak. "İslâmî Kaynaklarda ve Oryantalist Metinlerde Besmeleye Yaklaşımlar". Marife 21/1 (2021), 59-77. https://doi.org/10.33420/marife.913335

Plagiarism / Intihal: This article has been reviewed by at least two referees and scanned via a plagiarism software. / Bu makale, en az iki hakem tarafından incelendi ve intihal içermediği teyit edildi.

\section{(c) $)(1)(8)$}

Copyright / Telif Hakkl: "This article is an open access article distributed under the terms and conditions of the Creative Commons Attribution-NonCommercial-NoDerivatives 4.0 (CC BY-NC-ND 4.0) International License." / "Bu makale Creative Commons Alıntı-GayriTicari-Türetilemez 4.0 (CC BY-NCND 4.0) Uluslar arası Lisansı altında lisanslanmıştır."

e-ISSN: 2630-5550 


\section{İslâmî Kaynaklarda ve Oryantalist Metinlerde Besmeleye Yaklaşımlar}

Özet

Besmele hakkında erken dönemlerden itibaren birçok eser te'lîf edilmiştir. Bu kitaplar hem teknik anlamda besmelenin ilm-i kıraat ve İslâm Hukuku'ndaki konumunu tespit etmeye çalışmakta hem de Müslüman bireyler ve İslâm toplulukları üzerindeki etkisini belirgin kılmayı amaçlamaktadır. Makalede öncelikle ilmî, teknik, sanatsal ve aktüel önemi açısından İslâmi kaynaklarda besmelenin konumu Ebû Şâme el-Makdisînin ö. (665/1267) Kitâbü'l-Besmele isimli kitabı ve diğer temsil değeri yüksek te'lîfler çerçevesinde; oryantalist yaklaşım ise Nöldeke'nin ö. (1930) The History of the Qur'ān isimli, çağdaş oryantalizmin Kur'ân, kıraat ve Mushaf çalışmalarında başucu kitabı haline gelmiş kitabının İngilizce tercümesi ve diğer kaynaklar ele alınıp incelenecektir. Kur'ân-ı Kerîm ile doğrudan bağlantısı nedeniyle 'ulûmü'l-Kur'ân, ilimlerin en șereflisi ve değerlisi kabul edilmiştir. Bundan dolayı İslâm ulemâsı erken dönemlerden itibaren Kur'ân ve Kur'ânî ilimlere dair birçok eser kaleme almıştır. Çağımızda ilimleri bir bütün olarak kapsayan araștırmalar yapmak hayli zorlaştığından, branşlaşmak ve ilimleri dallara ayırmak ve sinıflandırmak suretiyle ihtisaslaşmak zorunlu hale gelmiştir. Bu çalıșmada, esasında her Müslümanın bildiği ve gündelik hayatının bir parçası kıldığı besmele konusu İslâmî kaynaklar ve özellikle Ebû Şâme'nin Kitâbüll-Besmele isimli eseri merkeze alınarak incelenecektir. Ebû Şâme'nin kitabı, kendisinden önce bu konuda oluşmuş literatüre de hâkim olması ve konuyu hem kıraat ulemasının kriterlerini hem de fakihlerin yaklașımlarını vermek suretiyle incelemesi açısından temsil değeri yüksek çalışmalardandır. Haddizatında kendisinden sonra bu konudaki te'lîfât onun kitabına müracaatı görev bilmiştir. Çalışmada aynı zamanda, özellikle Rönesans ve Reform hareketlerini müteâkip İslâmî ve Kur'ânî konu ve kavramlara dair ciddi araştırmalar yapan oryantalist yaklașım ile bir mukayese imkânı da verilmek istenmiştir. Bu manada diğer oryantalist eserler yanında kendisinden sonra söz konusu incelemelere hem konu hem de metod ve yaklaşım açısından büyük etkide bulunmuş Nöldeke'nin kitabı merkeze alınmıștır. Burada kitabın İngilizce tercümesi kullanılacaktır. Çağdaş dönem oryantalist çalışmalarda bu konunun Nöldeke'nin çalıșması temele alınarak değerlendirildiği görülmüştür. Makale, oryantalist değerlendirme tarzının İslâmi yaklaşımdan farklı bir hedef ve usule sahip olduğunu da ortaya koymak istemektedir. Bu minvalde oryantalist metinlerin, İslâmi rivâyetler arasında şâz olanları öne çıkarmak suretiyle Kur'ân'ı beşer katında oluşmuş bir kitap olarak değerlendirme şeklinde genellenebilecek tutumlarının besmele konusunda da mevcut olup olmadığı araștırılacaktır. Çağdaş oryantalizmin yeni bir yaklaşım teklif edip etmediği de tahlil edilecektir. Nöldeke kitabında, besmele konusunda Müslümanlar arasındaki muhalif tavrı ortaya çıkarmayı hedeflemiştir. Dolayıslyla böyle bir mukayesenin yapılması konuyu sahih bir șekilde değerlendirme için elzemdir. Çalışmanın bir diğer gayesi, İslâm ulemasının, ilmî faâliyetlerini İslâm'a hizmet etmenin bir yolu olarak gördüklerine dair bir örnek sunmaktır. Kur'ân'ın bütün sûrelerinin kendisi ile başlatıldığı bir nevi giriş anahtarı konumunda olması besmelenin İslâm uleması ve Müslümanlar arasında sahip olduğu konumun sebebini anlamak için yeterli olacaktır. Ayrıca Ebû Şâme'nin eseri çerçevesinde besmelenin akaid, kıraat, tefsir, hadis, fikıh, lügat, siyer, tarih gibi açılardan konumu kısa ve öz olarak sunulacaktır. Nöldeke'nin kitabı merkeze alınmakla birlikte gerektiğinde diğer oryantalist metinlerde de bu konuya yaklaşım incelenecektir. Oryantalist anlayıșın genel Kur'ân yaklaşımları ile besmele hakkındaki tavırlarının benzerlikleri, varsa farklılıkları kaydedilecektir. Aynı zamanda İslâmi nakle dayalı aktarım ve anlatım tarzı ile beșer mahsûlü bir eser olarak ele alınması manasında istişrâkî inceleme tarzının karşılaştırılması yapılmaya çalışılacaktır. Ayrıca, besmelenin Müslümanların bilgi ve hayat kaynakları olan Kur'ân ile onun pratize edilmişs şekli olan sünnetteki müessis rolünün tekrar gündeme taşınması da amaçlanmaktadır. Araştırma, Íslâmi kaynakları en üst düzeyde temsil ettiği düşünülen Ebû Şâme’nin ve oryantalist yaklaşımı belirleyici bir fonksiyona sahip olması açısından Nöldeke'nin eseri çerçevesinde gerçekleștirilecektir. Konunun çerçevesinin çizilmesinde bu iki kitaptaki alt başlıklar esas alınmiştır.

Anahtar Kelimeler: Kur'ân-ı Kerîm Okuma ve Kıraat Illmi, Besmele, İslâmi Kaynaklar ve Oryantalist Metinler, Ebû Şâme ve Kitâbü'l-Besmele, Nöldeke ve Kur'an Tarihi. 


\title{
Approaches to Basmala in Islamic Sources and Orientalist Texts
}

\begin{abstract}
Summary
Many works on basmala have been written since the early ages. These works both try to determine the position of the basmala in the Knowledge of Readings of Qur'ān ('ilm al-qiraat) and Islamic Law in the technical sense, as well as the effect of it on both Muslim individuals and Islamic societies. In this article, the position of the basmala in Islamic sources in terms of its scientific, technical, artistic and actual significance is mentioned. Besides other works of high representation value, the work of Abu Shama al-Makdisi d. (665/1267) Kitâbu'l-Basmala is particularly worth mentioning. In addition, the orientalist approach will be tried to be revealed by going to the texts. Among these works, the most important one is Geschichte des Qorāns (The History of The Qur'ān), which was written by Nöldeke d. (1930) on the history of the Qur'ān and became the bedside book of contemporary orientalism's Qur'ānic studies. Due to its direct connection with the Qur'an, the ulûmü'l-Qur'an was accepted as the most honorable and valuable of the sciences. Therefore, Islamic scholars have written many works on the Qur'an and Qur'anic sciences since the early ages. In our age, it has become very difficult to conduct studies that cover the sciences as a whole, so it has become common to specialize by branching and classifying the sciences. In this article, the subject of basmalah that every Muslim knows and makes a part of his daily life will be examined by taking Islamic sources and especially Abu Shāma's work named Kitâbü'l-Basmalah to the center. Abū Shāma's book is one of the works with high representation value in terms of having a command of the literature that was formed on this subject before him and examining the subject by giving both the criteria of the Qur'an scholars and the approaches of the jurists. Works written after him frequently made references to his work. In this study, it is also aimed to give an opportunity to compare with the orientalist approach, which has produced serious works on Islamic and Qur'anic issues and concepts, especially after the Renaissance and Reform movements. In addition to the orientalist works put forward in this sense, the work of Nöldeke, who has had a great impact in terms of both subject, method and approach in these studies after him, was taken into the center. The English translation of the work will be used here. In contemporary orientalist studies, it has been seen that this issue is evaluated on the basis of Nöldeke's work. The article also wants to reveal that the orientalist evaluation style has a different purpose and method than the Islamic approach. In his work, Nöldeke aimed to reveal the opposing attitude among Muslims on the issue of basmala. Therefore, making such a comparison is essential for an accurate assessment of the issue. Another purpose of the study is to provide an example of what Islamic scholars see their scholarly works as a way of serving Islam. The fact that all the surahs of the Qur'an are initiated with it is a kind of entry key will be enough to understand the reason of the position that the basmalah has among Islamic scholars and Muslims. In addition, within the framework of the work of Abū Shāma, the position of the basmala in terms such as 'akâid, qiraat, tafsīr, hadith, fiqh, grammar, sirah, history will be presented briefly. Approach to this subject will be examined in other orientalist texts when necessary, centered on Nöldeke's work. This will be tried to be carried out by comparing both the similarities and differences, if any, of the orientalist approach to the general Qur'anic approaches and the attitudes about the basmala, as well as the Islamic narrative and narrative style based on the Islamic narration, and the consultative study style in the sense that it is treated as a human product. This examination and comparison will be carried out within the framework of the work of Abū Shäma, who represents the Islamic sources at the highest level, and in terms of the representation of the orientalist approach, Nöldeke. In drawing the frame of the subject, the subtitles in these two works were taken as a basis.
\end{abstract}

Keywords: Recitation of the Qur'an and The Science of Qiraat, Basmala, Islamic Sources and Orientalist Texts, Abū Shāma al-Makdisī and Kitābu'l-Basmala, Nöldeke and The History of the Qur'ān.

\section{Giriș}

Kur'ân-ı Kerîm'in nüzûlünden itibaren, ona muhatap olacak kadar Kur'ân'ı tanıyan insanlar genel olarak iki şey arasında karar vermek mecburiyeti altında kalmışlardır. Bunlar; Kur'ân ile belirlenmiş itikat, düşünce ve hayat yolu ile Kur'ân'a muhalefet ile ortaya çıkan inanç, fikir ve hayat alanıdır. İşte bu iki hayat tarzının ilmî sahada temsilcileri, ilimler tarihi sahnesinde her zaman buluşmak ve 
bir şekilde etkileşmek zorunluluğu altında kalmışlardır. Bu etkileşim çağdaş araştırmacıların çalıştıkları konularda, kavramlarda ve hatta yöntemlerinde de ziyadesiyle kendini göstermektedir. Bazı önyargıların ve peşin hükümlerin ispatına yönelik araştırmaların yanında salt ilmî sâiklerle de olsa Kur'ân ve Kur'ân etrafında gelișen ilimler gayr-i Müslimlerin, özellikle batılıların sürekli ilgi alanı içerisinde kalmıştır. Bu minvalde, genel ya da özel İslâmî ve Kur'ânî kavramlar hakkında sayısız araştırmalar gerçekleștirilmiştir. ${ }^{1}$ Bu çalışmada, bu bahsedilen konulardan hem İslam uleması arasında bir şekilde farklı görüşlerin doğmasına sebebiyet vermiş hem de oryantalist çalışmaların ihtilaflı bir konu olmasının da verdiği ivme ile ilgisini çekmiș husûsî bir konu; "besmele" ele alınmıștır. Öncelikle konunun İslam uleması arasındaki değerlendiriliş tarzının ortaya konması ve sonrasında oryantalist bakış açısının en üst düzeyde temsilini sağlayan eserler çerçevesinde yaklaşımının billurlaştırılması amaçlanmıştır. ${ }^{2}$ İslam uleması arasında en kapsamlı bir şekilde ele alındığı eserler ve özellikle de Makdisînin konuya hasredilmiş kitabı merkeze alınmıştır. Oryantalist yaklaşımda ise klasik dönemin yanında modern/çağdaş dönem yaklaşım tarzı ve bu tarzın belirlenmesinde en büyük etkiye sahip Nöldeke'nin eseri çerçeveyi belirlemiştir. Bu konu özelinde mukayeseli bir çalışma eksikliği ve gerekliliği makalenin hazırlanmasındaki müessir etkenlerdendir. Bu noktası ile nev'i şahsına münhasır bir durum arz etmektedir.

\section{Sûre Bașlarında Bulunan Besmele Âyet midir?}

Mushaf'ta her sûreye giriş olarak yazılması, kıraat, tefsir ve fikıh uleması arasında besmelenin üç şekilde değerlendirilmesine yol açmıştır: İslam ulemâsı arasında besmeleyi sûrelerin bir âyeti olarak kabul edenler vardır. Bununla beraber ikinci bir ulemâ sınıfı onu müstakil bir âyet olarak kabul etmektedir. Üçüncü grupta ise bu iki kabulün dışında besmeleyi teberrüken yazılmış bir başlangıç ifadesi olarak gören âlimler vardır. Yani son kesimdeki ulemâya göre besmele âyet değildir. Bu başlık altında yukarıda kaydedilen üç farklı yaklaşıma sahip ulemanın görüşleri incelenecektir.

${ }^{1}$ Ebû Şâme'nin eserinin muhakkiki 65 adedi matbu diğerleri el yazması şeklinde Besmele hakkında yazılmış 111 kiap ve müellifinin listesini vermektedir. bk. Ebû Şâme Abdurrahmân b. İsmail b. İbrahim ed-Dimeșkî el-Makdisî, Kitâbü'l-Besmele, thk. Adnân b. Abdürrazzâk el-Hamevî el-Ğulebî (Abu Dabi: El-Mecme'u's-Sekâfî, 1425/2004), 72-80. Muhakkikin buradaki listede ismini vermediği ve eserde tarih belirtilmediğinden konuyu ele alan yazar tarafindan farklı karinelerle 1988'de tab' edilmiș olması muhtemel olan ve Fahreddîn er-Râzî̀ye ö. (606/1210) atfedilen besmele ve ahkâmına

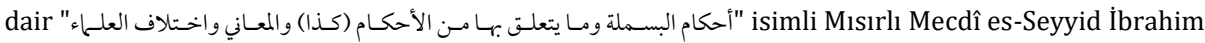
tarafından Dâru'l-Kütübi'l-Mısriyye'deki bir nüshaya (Teymûr 125) istinaden tahkik edilip Kahire'de Mektebetü'l-Kur'ân yayınevi tarafından basılan eserin Fahreddîn er-Râzîye nisbet edilmesinin yanlışlığı ve aslında bu çalıșmanın Ebû Şâme'ye ait Kitâbü'l-Besmele es-Sağîr olduğunu iddia eden bir çalışma için bk. Abdü'l-Hakîm Enîs, “Ahkâmü'l-Besmele” Leyse Li'l-Fahri'r-Râzî, 1434/2013, https://İslâmsyria.com/site/show library/377.

2 Buna bir örnek olması açısından son dönem Kur'ân çalışmalarının kendisinde yoğunlaştığı ansiklopedi olarak Encyclopaedia of the Qur'ān'daki "basmala” maddesine bakılabilir. William Alexander Graham, "Basmala", ed. Jane Dammen McAuliffe, Encyclopaedia of The Qur'ān (Leiden-Boston-Köln: Brill, 2001), I/210 vd. 


\subsection{Ebû Şâme'nin Eserinde Besmelenin Âyet Olması Meselesi}

Ebû Şâme, İslâmi kaynaklarda besmelenin müstakil veya sûrenin bir parçası olma anlamında bir âyet olup olmadığının önemli bir yer tuttuğunu vurgulamış ve bu konudaki yaklașımları verdikten sonra kendi konumunu belirlemiștir. Öncelikle, Neml sûresinde geçen ${ }^{3}$ besmelenin dışında bu konuda ulema arasında farklı görüşler olduğu bilinmektedir. Mezhepler arasında da farklı yaklaşımlar geliştirilmiștir. Bununla beraber Mesâhif-i Osman'da Tevbe (Berâe) sûresi hariç diğer bütün sûrelerin başında besmelenin yazıldığı (mersûm) hususunda ittifak vardır. İhtilaf, bu besmelelerin başlı başına bir âyet olup olmaması noktasında vuku bulmuştur. Mesela, konuyu ele aldığı yerde Süyûtî’nin belirttiği üzere İmam Şaffiî̀ye ö. (204/820) göre besmele hem Fâtiha hem de diğer sûrelerin bir âyetidir. ${ }^{4}$ Mâlikîler ise Neml sûresinde bulunan dışında Kur'ân'daki besmelelerin âyet olmadığı görüşündedirler. Bundan dolayı onlara göre namazda ne gizli ne de açı besmele çekmek gerekmez. Onlar, Medîne, Şam ve Basra kıraat imamlarının okudukları gibi "انعمت عليهم" ifadesini âyet sonu olarak almak suretiyle Fâtiha'nın yedi âyet olduğu-

nu kabul etmektedirler. Dolayısıyla yedinci âyet, "غير المغضوب" ile başlayan bölüm

olmaktadır. ${ }^{5}$ Onlar bu hususta kıraat imamlarının tercihini asıl kabul etmişlerdir. Hanefiler de Mâlikîler gibi besmelenin ne açıtan ne de gizli olarak okunmasını namazın şartlarından görmektedirler. Onlara göre besmele, Fâtiha'nın veya diğer sûrelerin bir âyeti değildir. Bununla beraber müstakil bir âyet olup olmadığında ihtilaf etmişlerdir. Ebû Hanîfe ö. (150/767) besmeleyi Fâtiha'dan veya diğer sûrelerden bir âyet olarak kabul etmezken Hanefî mezhebinde sûre başlarında besmelelerin müstakil birer âyet olduğu kabul edilmiștir. Ebû Şâme, bu farklılıklarl, Mushaflarda resmedilmemekle beraber okunuşta farklılıkları olan kıraat ihtilaflarına ("مصيطر" v" vaيطة", vb) benzetmekte ve bunda bir beis görmemektedir.

Ayrıca bunu kıraat farklılıkları gibi Kur'ân'ın yedi harf üzere inzal olmasının bir neticesi olarak değerlendirmektedir. Yani ona göre bütün bu görüşler sahihtir. ${ }^{6}$ Dolayısıyla bugün elimizde bulunan Mushaflarda Fâtiha'nın bir âyeti olarak besmelenin resmedilmiş olması, fıkıh mezhep imamlarının değil kurrâ'nın tercihine istinad etmektedir. Bazı şâz kıraatler hariç, kıraat imamlarının çoğu, Fâtiha'nın başındaki besmelenin sûrenin ilk âyeti olduğunu kabul etmişlerdir.7 Günümüzdeki

3 en-Neml 27/30.

${ }^{4}$ Süyûtî ö. (911/1505) de Âyetü'l-Kürsî'nin bir âyet olduğu nasıl muhkem ise besmelenin de Kur'ân'dan olduğu aynen sâbit ve muhkemdir görüşündedir. Ona göre bütün sahih kıraatlerde bu aynen geçerlidir. Bu değerlendirmeler için bk. Abdurrahmân b. Ebî Bekr b. Muhammed b. Celâleddîn esSüyûtî, Mîzânü'l-Ma'dele fî Şe'ni'l-Besmele, thk. Abdü'l-Hakîm el-Enîs (Dubâî: Şebeketü'l-Elûke, 1438/2016), 225-226.

5 Klasik İslâm ulemasının bu ihtilafına dair ayrıca bk. Ebü'l-Kâsim Cârullâh Mahmûd b. Ömer ezZemahșerî, Tefsîru'l-Keșşâf, tlk. Halîl Me'mûn Şîhâ (Beyrut: Dâru'l-Ma'rife, 1430/2009), 25. Burada Zemahșerî ö. (538/1144), bunun Araplar arasında her türlü hayırlı iște teberrüken kullanılagelen bir ifade olduğunu söyler. Yani ona göre Kur'ân sûrelerinin besmele ile başliyor olması bu âdetin bir gereğidir. Aynı yerde farklı vecihleri ele almak suretiyle bunun güzel bir başlangıcın ifadesi olduğu ve bir kutsallık atfetmenin şart olmadığını iddia eder.

${ }^{6}$ Ebû Şâme el-Makdisî, Kitâbü'l-Besmele, 111-122.

7 Bu konuya dair farklı görüşlerin ortaya çıkmasında “'addü'l-ây" meselesinde yapılan tercîhin yattığ anlaşılmaktadır. Mevzuyu özel başlık altında ele aldığı yerde Mekkî b. Ebî Tâlib’in ö. (437/1045) 
Mushaflar "addü'l-ây" meselesinde tercih edilen ekole göre yazılmaktadır. Süyûtî de Fâtiha sûresini tefsir ederken sûrenin başındaki besmelenin Fâtiha'dan bir âyet olduğuna dair birçok farklı rivâyeti zikrederek kendisi de besmelenin Fâtiha'nın bir âyeti olduğu şeklindeki bu nakillere katıldığını belirtmektedir. ${ }^{8}$ İki sûre arasında geçiş yapılacak olursa besmelenin okunup okunmayacağı da kıraat uleması arasında farklı görüşlere yol açmıştır. Nahl sûresi 98. âyetinde emredildiği üzere gerek sûrenin bașından gerekse ortasından kıraate bașlansın isti'âze vücûbiyyeti hususunda kıraat uleması arasında bir ittifak olmakla beraber ${ }^{9}$ bir bașka sûreye devam edilecek olursa besmelenin okunup okunmayacağı konusu ihtilaflıdır. ${ }^{10}$ Besmelenin kıraatin başında veya ortasında, özellikle iki sûre arasındaki geçişlerde okunmasının hem kıraat ulemasının kriterleri hem de fukahâ açısından vücûbiyyeti hakkında birçok ihtilaf meydana gelmiştir. Bunun en önemli nedeni olarak Mesâhif-i Osman'da sûre başlarında kitâbeten konulmuş yani resm-i Osmânî'de yer almış olması gösterilmiştir. Sorunun kaynağı, bunun vücûbiyyet mi ifade ettiği yoksa sahâbenin bir sünneti olarak teberrüken mi konulduğunda yatmaktadır. ${ }^{11}$

belirttiği üzere Kûfe ve Mekke ekolü Fâtiha'nın başındaki besmeleyi âyet olarak kabul ederken Basra, Şam ve Medine ekolü onu sûrenin başında bir âyet olarak almamaktadır. Mekkînnin kendisinin, besmeleyi sûre başlarında teberrüken okunan bir başlangıç ifadesi olarak kabul ettiği, bununla beraber hem fikıh hem de kıraat ulemasının tercihlerinin verildiği değerlendirmeleri için bk. Mekkî b. Ebî Tâlib el-Kaysî, el-Keșf 'an vücûhi'l-kirâ'âti's-seb' ve 'ilelihâ ve hücecihâ, thk. Muhyiddîn Ramazan, (Beyrut: Müessesetü'r-Risâle, 1404/1984), 13-24.

${ }^{8}$ Kaynaklarda konuyla alakalı rivâyetleri ve ulemanın değerlendirmeleri için bk. Abdurrahmân b. Ebî Bekr b. Muhammed b. Celâleddîn es-Süyûtî, ed-Dürru'l-Mensûr fi't-Tefsîri'l-Me'sûr (Beyrût: Dâru'l-Fikr, 1433/2011), I/11, 12, 19-24. İki sûre arasında geçiş yapılacak olursa besmelenin okunup okunmayacağı da kıraat uleması arasında farklı görüşlere müncerdir. Bu konudaki farklı okuyuş şekillerini görmek için bk. Dürru'l-Mensûr, 130-131. Ayrıca bk. Saçaklızâde Muhammed b. Ebî Bekr elMer'aşî, Cühdü'l-Mukıl, thk. Sâlim Kaddûrî el-Hamed (Ammân: Dâru Ammâr, 1429/2008), 319-320. Saçaklızâde ö. (1145/1732), "Dânî'nin açıkladığı üzere Fâtiha icmâ ile 7 âyettir" demektedir. Fakat besmelenin ondan bir âyet olup olmadığı hakkında fikıh ulemâsı arasında ihtilaf vardır. Saçaklızâde bu ihtilaflara değinmekte ve kendisi hangisini tercih ettiğini belirtmeksizin Neml sûresinin bir âyeti olduğunda hiçbir ihtilaf yoktur demektedir. Saçaklızâde el-Mer'aşî, Cühdü'l-Mukıl, 320.

${ }^{9}$ Ebû Şâme'ye göre burada kastedilen fikhî anlamda değil lügat'in gerektirdiği anlamda vücûbiyyettir. Ebû Şâme Abdurrahmân b. İsmail b. İbrahim ed-Dimeșkî el-Makdisî, İbrâzü'l-Me'ânî min Hirzi'lEmânî, thk. İbrahim Atve 'Avad (Kahire: Dâru'l-Kütübi'l-'Illmiyye), 61. "Kitâbü'l-İsti'âze" bașlı̆̆ı altında o, kıraat imamlarına göre isti'âzeden maksadın tilâvete başlamadan önce okunan "Allahım beni koru!" anlamında bir dua olduğunu belirtir. Buna göre besmeleden farklı olarak bazı şâz kıraatler dıșarıda bırakılacak olursa bütün selef ulemasına göre kıraate nereden bașlanırsa bașlansın isti âze çekmek vaciptir. İsti'âze'nin şekli, kıraat imamlarının tercihleri, konuya mahsus te'lîf edilmiş eserler ve bu konuda vârid olmuş bütün rivâyetlerin zikredilerek geniş bir şekilde değerlendirilmesi için bk. Ebû Şâme el-Makdisî, İbrâzü'l-Me'ânî min Hırzi'l-Emânî, 61-64.

${ }^{10}$ Ebû Şâme el-Makdisî, Kitâbü'l-Besmele, 130-131. Mesela iki sûre arası vasledildiğinde acaba besmele ile mi yoksa besmelesiz ve kıraat imamlarından Hamza'nın ö. (156/773) yaptığı gibi sekte ile mi geçiş yapılacağı konusunda imamlar arasında özellikle Verș ö. (197/812), İbn Âmir ö. (118/736) ve Ebû Amr ö. (154/771) farklı görüşlere sahiptir. Ebû Şâme'ye göre ihtilafın sebebi, bu imamlardan bu konuya dair bir metnin ulaşmamış olmasından kaynaklıdır. bk. Makdisî, İbrâzü'l-Me'ânî min Hırzi'lEmânî, 66. Konu Kur'ân tilâvet âdâbı bahsinde de ele alınmıștır. Bunun için bk. Gânim Kaddûrî elHamed, el-Müyesser fí 'ilmi't-Tecvîd (Cidde: Merkezü'd-Dirâsâti vel-Ma'lûmâti'l-Kur'âniyye, 1430/2009), 18-19.

11 Mekkî b. Ebî Tâlib el-Kaysî, el-Keșf 'an vücûhi'l-kirâ'âti's-seb', 14. Benzer bir değerlendirme için bk. Ebû Şâme el-Makdisî, İbrâzü'l-Me'ânî min Hırzi'l-Emânî, 65. Aynı yerde bahsedilen resmolunmuşluk sebebi ile kıraat ulemasının nasıl bir ictihâda gittikleri tek tek belirtilmektedir. 
İbnü'l-Cezerî ö. (833/1429) en-Neşr'de besmelenin kıraat ve fikıh imamları arasında Kur'ân'ın bir âyeti olarak kabul edilip edilmemesine dair hususları beş başlık altında ele almaktadır. Ona göre bu yaklaşımlar nefy ve isbât'a râcîdir ve her iki görüş de sahihtir. Konuya dair söylenenler haktır. O, bahsedilen ihtilâfların kıraat farklılıkları gibi olduğu görüşündedir. ${ }^{12}$ İbnü'l-Cezerînnin aktardığı üzere Sehâvî, Fâtiha'nın başındaki besmele konusunda kurrânın ittifak ettiğini söyler. 0 devamla, İbn Kesîr, 'Âsım, Kisâî ve onları takip edenlerin besmeleyi Fâtiha'dan ve bütün sûrelerden bir âyet olduğunu söylediklerinni belirtir. Hamza da özellikle Fâtiha konusunda onlara muvâfakat etmiștir. Ebû Amr, Kālûn ve Medine kurrâsından ona tabi olanlar besmelenin Fâtiha'dan bir âyet olmadığı görüşündedirler. ${ }^{13}$

Tevbe sûresinin başında besmelenin yer almıyor oluşu İslâmi gelenekte genel olarak iki şekilde anlaşılmıştır: 1- Esasında Enfâl ve Tevbe sûreleri tek bir sûre idi, daha sonra böyle bir ayrıma gidildi. 2- Berâe (Tevbe) sûresi kılıçla inmiş bir sûredir. Bundan dolayı merhametin sembolleştirilmiş şekli olan besmele ile başlaması olası bir şey değildir. ${ }^{14}$ Klasik dönem müfessirleri genelde eserlerinin ilgili yerinde konu ile ilgili değerlendirmelerde bulunmuşlardır. ${ }^{15}$ Konu hakkında farklı yaklaşımları da verdiği yerde Kurtubî ö. (671/1273), Araplar arasında câhiliyede bir anlaşma nakzedileceğinde besmele yazmamanın bir âdet olduğunu belirtir. Bu sözlerden besmelenin İslâm öncesinde de bilinen ve kullanılan bir teberrük cümlesi olduğu neticesine ulaşmak mümkündür. Bu yaygın gelenek dolayısıyla, Müslümanların müşriklerle arasındaki ahdi nakzeden bu sûrenin başında besmele konulmamıștır. ${ }^{16}$ Besmeleye dair yazdığı müstakil eserde Ali el-Kârî ö. (1014/1605) de kurrâ imamlar arasında Tevbe sûresinin besmele ile başlamadığında ittifak olduğunu bildirir. Aynı zamanda bu sûrenin dışındaki bütün sûrelerin başında bes-

12 Ebü'l-Hayr Șemsüddin Muhammed b. Muhammed İbnü'l-Cezerî, en-Neșr fi'l-kırâ'âti'l-'așr, nșr. Muhammed Ali ed-Debbâ' (Beyrut: Dâru'l-Kütübi'l-ilmiyye, 1985), 270.

${ }^{13}$ Bu beş görüş olarak da şunları vermektedir: "1- Besmele, sadece Fâtiha'nın bir âyetidir. Bu Mekke, Kûfe (kıraat imamlarının) ve onlara muvafakat edenlerin görüșüdür. Bu konuda Şâfiî’den de bir görüș rivâyet edilmiștir. 2- Onun Fâtiha'nın ve bütün diğer sûrelerin evvelinde bir âyet olduğu șeklindeki Şâfiîlerin ve ona muvafakat edenlerin genel görüșüdür. Bu konuda Ahmed'den de bir rivâyet vardır ve yine bu görüş Ebû Hanîfe'ye de nisbet edilmiştir. 3- Şâfî̀'ye ait ikinci bir görüşe göre o, Fâtiha'nın başında bir âyettir ve onun dışındaki sûrelerin de bir âyetidir. 4- Besmelenin her sûrenin başında o sûreden olmayan müstakil bir âyet olduğu fikrinde olanlar. Bu, Ahmed (b. Hanbel)'in meșhur görüşüdür. Dâvûd ve takipçileri de bu görüştedir. Ebûbekir er-Râzî, Ebû Hanîfe'nin takipçilerinin ileri gelenlerinden Hasan el-Kerhî'den de buna dair bir rivâyet nakletmiștir. 5- Bir görüşe göre de besmele, ne Fâtiha'nın ne de diğer sûrelerin başında bir âyettir. 0 bir âyet değildir. Teberrüken ve güzel bir başlangıç için yazılmıştır. Bu, Mâlik, Ebû Hanîfe, Sevrî ve ona uyanların görüşüdür. Onlar, besmelenin Neml Sûresi'nden bir âyetin bir kısmı olduğu ve besmelenin bir kısmının Fâtiha'dan bi âyet olduğunda ittifak etmişlerdir." İbnü'l-Cezerî, en-Neșr, 270-271. Süyûtî de Fâtiha'ya nisbet edilmesi noktasında besmelenin konumunu sahih kıraatlerdeki harf ve kelimelerin konumu gibi görmektedir. Süyûtî, Mîzânül'-Ma'dele, 230.

14 İbnü'l-Cezerîye göre Berâe (Tevbe) sûrenin evvelinde besmelenin yer almadığı noktasında kıraat imamları arasında herhangi bir ihtilaf yoktur. Ebü'l-Hayr İbnü'l-Cezerî, en-Neşr, 264.

${ }^{15}$ Mesela bk. Zemahșerî, Keş̧̧âf, 421.

${ }^{16}$ Ebû Abdillah Muhammed b. Ahmed b. Ebî Bekr el-Kurtubî, el-Câmi' li-Ahkâmi'l-Kur'ân ve'l-Mübeyyin limâ Tedammenehû mine's-Sünneti ve Âyi'l-Furkân, thk. Abdullah b. Abdü'l-Muhsin et-Türkî (Beyrut: Müessesetü'r-Risâle, 1427/2006), X/93. 
melenin okunacağına dair de kurrâ arasında ittifak vardır. Fakat iki sûre arasında (Tevbe hariç) okunup okunmayacağına dair ihtilaf vardır. İtimad edilen görüş ise ona göre caiz olmadığıdır. ${ }^{17}$

Oryantalist yaklaşımın kendisi ile temellendiği eserinde Nöldeke'nin belirttiğine göre ise, ortaya konulan sebepler arasında sahabenin Enfâl ve Tevbe sûrelerinin ayrı mı tek mi olduğu arasında ihtilaf etmiş olmalarını en güçlü neden olarak görür. ${ }^{18}$ Bundan dolayı onlar, bu iki sûreyi besmeleyi koymaksızın birbirinden ayırmışlardır. Ona göre birbirinden kronolojik olarak uzak ve mâhiyetleri farklı ve ayrıca dokuzuncu sûrenin ilk âyetinin tamamı ile ayrı bir konuyu ele alıyor olması dolayısıyla sahabenin bu iki sûreyi birbiri ile irtibatlandırmaya çalışıyor olmaları anlaşılabilir bir durum değildir. Kur'ân'ın editörleri olarak isimlendirdiği müstensihlerin bu meseleyi çözmek için kendilerinden yardım aldıkları noktaların da muğlak ve önemsiz olduğu kanaatindedir. Nöldeke, bunun ya Hz. Osman zamanında yapılan istinsah esnasında meydana gelen bir yazı hatası ya da hâricî nedenlerden kaynaklanan bir eksiklik olduğu kanaatindedir. Sonra gelenler bunu bilseler de Kur'ân'da bir değişiklik yapıyor olmak gibi bir itham ile karşılaşmamak için böyle bir düzeltme yapmaya yanaşmamışlardır. ${ }^{19}$

Modern/çağdaş oryantalistlerden Wansbrough ö. (2002) bu konuyu ele aldığı yerde meseleye İbn Arabî̀nin ö. (543/1148) ahkâm âyetlerinin tefsirine dair eseri Ahkâmü'l-Kur'ân ${ }^{20}$ penceresinden yaklaşmaktadır. Ona göre elimizdeki kabul edilmiş olan Kur'ân metni her zaman gerekçelendirilebilir ve hatta bir avantaja

${ }^{17}$ Ali b. Sultan Muhammed el-Kârî, el-Mes'ele fi'l-Besmele, thk. Abdül-Hakîm el-Enîs (Dubâî: Şebeketü'lElûke, 1434/2012), 23.

18 Nöldeke'nin buradaki tercihi, Kurtubî'de sıralanan beş görüşten dördüncüsüne tekâbül etmektedir. Kurtubî burada bu görüște olanların Ebû İsme ve başkaları olduğunu söyler. Buna göre Hz. Osman zamanında Mushaf yazıldığında sahabe bu iki sûrenin ayrı mı aynı mı olduğunda ihtilaf etmiştir. Bu iki görüş sahibinin de razı olmaları için iki sûre arasına bir boşluk bırakıldı. Ona göre bu şekilde ayrı sûre olduğunu iddia edenler tatmin oldu. Bașına besmele konulmamak suretiyle de bunların tek sûre olduğunu iddia edenler razı olmuş oldu. Bu iki şekli ile Mushafa kondu. Bu değerlendirmeleri için bk. Ebû Abdillah EbEi Bekr el-Kurtubî, el-Câmi', X/95.

19 Nöldeke, İbranice İncil'in metinsel formundaki birçok gelișmenin de aynı kaderi paylaștığı ve değișime uğradığı kanaatindedir. Theodor Nöldeke vd., The History of the Qur'ān, ed. - çev. Wolfgang H. Behn (Leiden-Boston: Brill, 2013), 278. Bunun salt bir metin yazımı hatası olduğu iddiasının tekrarı için ayrıca bk. Nöldeke vd., The History of the Qur'ān, 246.

20 İbnü'l-Arabî, besmelenin düşürülmesine dair başlı̆̆ altında âlimlerin bu konuda 4 grup oluşturduklarını söyleyerek bunları şu şekilde sıralamaktadır: Mâlik ö. (179/795) ve İbn Aclân'dan ö. (148/765) gelen bir görüşe göre Tevbe sûresi Bakara'ya muadil bir uzunlukta idi fakat sonradan bir kısmı alındı. İște bu sırada onun ilk bölümü ile beraber besmele de gitmiş oldu. İkinci görüşe göre Berâe bir kızgınlık iken besmele bir rahmettir ve bu ikisinin arası cem olmaz. Üçüncü görüșe göre Berâe (Tevbe) sûresi emân'ın kaldırılması ile nazil oldu; besmele ise emân demektir. İbnü'l-Arabî, bütün bunların uzak veya yakın ihtimaller olduğunu söyler. Bunların en uzak ihtimal olanı ise onun küfrün zikredilmesi ile başlatıldığı görüşüdür. Zira bu şekilde başlayan ve başında besmele bulunan birçok başka sûre vardır. Ona göre en doğru olan görüş; Yezîd el-Fârisînnin İbn Abbâs'dan ö. (68/68788) rivâyetle bildirdiği bir haber ile sabit olan görüștür. Buna göre Hz. Osman'a ö. (35/656) mushafa besmeleyi niçin almadığı sorulduğunda o, Enfâl'in ilk inzal olunan Tevbe'nin ise son nazil olanlar arasında olduğunu ve Rasûlullah da vefat edip bu konuda bir açıklama yapmadığından, bu iki sûredeki konuların benzerliği dolayısıyla ben Berâe'nin Enfâl'den olduğunu sandım ve o ikisini bir araya aldım demiștir. Ebûbekir Muhammed b. Abdullah ibnü'l-Arabî, Ahkâmü'l-Kur'ân, thr. - tlk. Muhammed Abdülkadir Atâ (Beyrut: Dâru'l-Kütübi'l-İlmiyye, 1424/2002), 2/445. 
çevrilebilir. 0, fikrine destek vermek üzere Enfâl sûresi ile Tevbe sûresi arasında besmelenin olmamasını bir örnek olarak sunar. Ona göre İbnü'l-Arabî meseleyi, sadece bu iki sûre arasındaki konu benzerliği dolayısıyla değil kıyasın ilâhî kökenine dair bir delil olarak ele almaktadır. Ona göre İbnü'l-Arabî'nin argümanı, bir nass olmadığında, sahabenin başlangıçta ayrı olan iki vahyin kıyâsî olarak yan yana koymasına neden olduğu idi (sahabe klyâsı). Wansbrough'a göre bu çözüm, Nöldeke-Schwally'nin, cihad buyrukları tartışıldığından dolayı bu iki sûrenin aynı olduğunu kabul etmelerinden daha az mantıklı değildir. Hatta Wansbrough, Cessâs'ın ö. (370/981) görüşüne göre, yalnızca kıyas değil, diğer tüm kanıtlayıcı yöntemlerin de kutsal metinlerden türetilebileceği iddiasında bulunmuştur. ${ }^{21}$

\subsection{0ryantalist Metinlerde Besmelenin Bir Âyet Olarak Değerlendirilmesi}

Oryantalist metinler, klasik İslâmi kaynaklarda bulunan ve besmelenin bilinen geleneksel şekline benzerliği ile ona bir nevi öncülük ettiği söylenen kelime yapılarına dikkat kesilir. Zemahșerî'nin "Lât veya 'Uzzâ'nın ismi ile başlarım” șeklinde bir formülün varlığını zikretmesi bunlardandır. ${ }^{22}$ Burada İslâm öncesi Arap bölgelerinde kullanılan kavramların ve yine putlara hitap şeklinin İslâmi söylem ve eyleme büyük katkıları olduğu ve hatta oradan aktarma olduğu fikri merkeze alınır. Sadece İslâm öncesi Arap kültüründe var olan şekillere değil aynı zamanda Kur'ân öncesi dînî metinlerdeki kullanımlara bakılır. Nöldeke, Fâtiha sûresinde kullanılan çoğu kavramın Yahudi ve Hristiyan kutsal metinlerinde yer alan İbrânice ifade şekillerinin bir tekrarı olduğunu ve orijinal olmadıklarını iddia eder. Ona göre farklı kıraat imamları ve fakihler arasında Fâtiha sûresinin yedi âyet olarak bölümlenmesinde yaşanan ihtilaflar da bundan dolayıdır. Yani aslında "عليهم şeklinde bir fâsıla akışla uyuşmamakta ve bundan dolayı bir çıkış yolu olarak besmele bir âyet olarak kabul edilmektedir. Bu da ona göre, sonradan gerçekleştirilmiş bir uyarlama faaliyetidir. Nöldeke’ye göre Zemahşerî ve Beyzâvî'nin ö. (685/1286) de söyledikleri üzere bu sûrenin âyet sayısı hakkında sadece yedi âyet kararı yoktur; daha çok veya az sayıda âyet sayısı belirten görüşler de vardır. Nöldeke, şayet altı sayısı kabul edilecek olsa "seb'u'l-mesânî" anlayışının yıkılacağını savunur. Yine o, diğer birçok Kur'ânî kavram için uyguladığı üzere besmelenin Eski ve Yeni Ahid'in "Tanrı'nın adı ile başlarım” șeklindeki formülasyonun bir neticesi olduğunu iddia eder. ${ }^{23}$ Besmele maddesinde Graham'ın belirttiği üzere Lüb-

${ }^{21}$ John Wansbrough, Qurānic Studies: Sources and Methods of Scriptural Interpretation, çev. Andrew Rippin (New York: Prometheus Books, 2004), 190.

${ }^{22}$ Bu ifade için bk. Zemahșerî, Keşşâf, 25.

23 "Arapların "tesmiye" veya genel olarak "besmele" olarak adlandırdıkları "Tanrı Adına" şeklinde başlayan giriş kelimelerinin izleri İncil'in söyleyiş tarzına (telaffuz) kadar sürülebilir.” Nöldeke vd., The History of the Qur'ān, 92-94. Ona göre ihtilaflı olduğu için sûre başları dişarıda bırakılırsa Kur'ân'da Fâtiha ve Neml sûrelerinde geçen besmele Yahudi kaynaklarına kadar geri götürülebilecek bir başlangıç cümlesidir ve hiçbir orijinalliği söz konusu değildir (özellikle revizyonist ekolde yankısını çok daha güçlü bulacak bir şekilde oryantalist yaklaşımda Kur'ân'ın kendisinden önceki kutsal metinlerden hem anlam hem de kavram olarak çok şey aldığı ve onların ucuz bir taklidi olduğu yargısı hâkimdir). Nöldeke'ye göre her ne kadar Hz. Peygamber bizzat kendisi bir şekilde besmelenin vahyin bir parçası olduğunu belirtmişse de gelenek, bunu vahyin en eski parçası olarak kabul etmektedir. Yani bu anlayış içerisinde gelenek, yeni bir şekillenme içerisinde değerlendirilmektedir. 
nanlı Fransız papaz, hayatını Hristiyanlık ile İslâm arasında (dinler arası) diyaloğa adamış İslâmcı, Arapça uzmanı ve oryantalistlerin ileri gelenlerinden Louis Massignon'un ö. (1962) talebesi olan Youakim Moubarac ö. (1995) da Allah, Rahmân, Rahîm üçlemesinin arkasında Yahudi-Hristiyan ve Güney Arap putperestlerinin kavram ve anlayışlarının bir koalisyonunu görmektedir. ${ }^{24}$

Oryantalist metinlerde ilk dönem kaynaklarında besmelenin namazlarda Fâtiha'nın başında açıktan okunup okunmayacağına dair Fıkhî ekoller arasındaki ihtilafların bir benzerinin aslında hem besmelenin hem de Fâtiha'nın Kur'ân'ın bir parçası olup olmadığı konusunda da var olduğu iddia edilir. ${ }^{25}$ Acaba bunlar Kur'ân'dan mıdır yoksa sadece Hz. Peygamberin dua mahiyetinde okumuş olduğu şeyler midir? Nöldeke, eserinin özel başlık ayrılmış bölümünde sûre başlarında bulunan besmeleleri yine sûre başlarında bulunan hurûf-i mukatta'a ile karşılaştırarak ele alır. Her ne kadar bu harfler sûrenin ilk âyetleri olarak kabul edilmiş ise de Nöldeke İslâmi ekoller arasında besmeleye dair farklılıkları zikreder. Bu farklılıklar şunlardır: Mekke ve Kûfe kıraat imamları onları ayrı birer âyet olarak kabul etmektedirler. Medine ile Şam kıraat imamları ise besmeleyi sûreleri birbirinden ayıran, teberrüken konulmuş, bununla beraber ayrı bir âyet olmayan başlangıç ifadeleri olarak almışlardır. Buradan onun da besmele meselesini kıraat imamlarının yaklaşımı doğrultusunda ele aldığı anlaşılmaktadır. Bu konuda belirleyici unsur fikhî mezhepler değil kıraat imamlarının yaklaşımı olmuştur. Bundan dolayı Nöldeke, bunun Hz. Hafsa ö. (45/665 [?]) ve Hz. Osman öncesi sahabe Mushaflarında yer almış bir şey olduğu kanaatine varmıştır. Bu yaklaşıma ulaşmasında, besmelenin Mushaflara ilk olarak Hz. Osman tarafından konulmuş bir şey olduğuna dair herhangi bir rivâyet gelmemesi etkili olmuştur. ${ }^{26} \mathrm{~Hz}$. Peygamberin Hudeybiye musâlahasının başına besmeleyi koymuş olması onun zaten bunu kullandığını gösterirken acaba şu anda kullanılan formu başından itibaren muhafaza edilmiş tarz mı idi yoksa farklılıklar geçirmiş midir konusunda farklı rivâyetlere ulaşmak mümkündür. Ona göre putpereset, Yahudi ve Hristiyan Araplar arasında birçok mektup ve risaleye bu şekilde başlandığı bilinmektedir. ${ }^{27}$ Graham, Mecûsîler arasında "pad nām ī yazdan" ("tanrı(lar)ın adı ile”) şeklinde bir başlangıç şeklinin Paikuli'de üçüncü asırdan itibaren kullanımda olduğunu bildirir. ${ }^{28}$

bk. Nöldeke vd., The History of the Qur'ān, 95.

24 Graham, "Basmala”, 208; Moubarac'ın bu değerlendirmelerinin yer aldığı orijinal eseri için bk. Youakim Moubarac, Les études d'épigraphie sud-sémitique et la naissance de l'Islam: Eléments de bibliographie et lignes de recherches (Paris: Librairie orientaliste Paul Geuthner, 1957), 58-61.

${ }^{25}$ Nöldeke, Fâtiha'nın Yahudi ve Hristiyan âyinsel metinlerine bağımlılığı ile dikkat çektiğini iddia eder. Nöldeke vd., The History of the Qur'ān, 246.

${ }^{26}$ Nöldeke, istinsah öncesi Mushaflarda sûrelerin birbirinden boşluk bırakılmak suretiyle mi, bir işaret konularak mı ayrıldığı noktasında kesin bir kanıtımızın olmadığını iddia eder. Mesela Zemahşerı̂’ye göre Übey İbn Kâ'b'ın ö. (33/654 [?]) mushafında Fîl ve Kureyș sûreleri fâsılasız yani tek sûre olarak kaydedilmiştir. Eğer bu doğru kabul edilirse diğer sûrelerin besmele ile birbirinden ayrıldıkları da zımnen kabul edilmiş olur ki bu durumda diğer Mushafların da kendisine istinad ettiği Hafsa mushafında sûrelerin başında besmelenin konulmuş olduğu kabul edilmesi gerekir. Nöldeke vd., The History of the Qur'ān, 249.

27 Değerlendirmeler için bk. Nöldeke vd., The History of the Qur'ān, 277.

${ }^{28}$ Graham, "Basmala", 208. 
Graham'ın bildirdiği üzere Régis Blachère'e ö. (1973) göre besmele, Hz. Peygamber tarafından mektupları ve yaptığı anlaşmaları kendisi ile başlattığı bir başlangıç ifadesidir. Bundan dolayı sûrelerin başlangıçlarını da bu şekilde başlatmayı uygun görmüştür. Yani besmele, Peygamber tarafından icad edilmiş bir şeydir. Yine Graham'dan öğrendiğimize göre R. Paret ö. (1983) ise "es-seb'u'l-mesânî" ifadesinin yerini bulması için besmelenin Fâtiha sûresine bir âyet olarak sonradan ilave edildiğini iddia eder. Angelika Neuwirth d. (1943) ise Hristiyan ve Yahudi ayinsel formlarından ve Fâtiha'nın kendi yapısal özelliklerinden ve mâhiyetinden yola çıkarak yaptığı değerlendirmede besmelenin Fâtiha sûresinin bir âyeti olmadığı kanaatine varmıştır. ${ }^{29}$ Açe Müslümanları üzerine yaptığı çalışmasında John Bowen d. (1951), Fâtiha'nın başında besmelenin açıktan okunması meselesinin Açe'de bulunan Gayo topluluğu arasında gelenekselci ve modernist ayrımını belirleyecek derecede ciddi bir anahtar kavram haline geldiğini belirtir. ${ }^{30}$ Nöldeke ve günümüze kadar onu takip eden diğer oryantalistlerde bunun ilahi bir özünün olmadığı, ancak kendisinden önce benzerlerine bir öykünme veya sonradan durumu kurtarmaya yönelik İslâm ulemasının bir ihdası olduğu şeklinde bir yaklaşım görünmektedir

\section{Besmelenin Anlamı}

Klasik kaynaklar, besmelenin anlamı, "besmele" veya "tesmiye" şeklinde isimlendirilmesi, besmele cümlesinde geçen kavramların manası, iștikâkı, kökeni gibi konulara yer vermişlerdir. Bunun yanında, İslam öncesi dönmelerde ve farklı kültürlerde aynı kullanımın veya benzerinin bulunup bulunmadığı da ayrı bir inceleme konusu yapılmıștır. ${ }^{31}$

\section{1.İslâmi Kaynaklarda ve Oryantalist Yaklașımda Besmele Kavramı}

Besmele öncelikle Kur'ân'da birçok başka yemin şekli ve ifadelerinin arasında Kur'ân elifbâsı'nın ikinci harfi olan "bâ" harf-i ceri'nin ismin başına gelmesi ile oluşturulmuş bir yemin şeklidir. البسملة kelimesi بسمل fiilinin mastarıdır. Nasıl ki kelime-i tevhidin söyleniși için kısaltılmıș bir șekilde "tehlîl" ve yine Allah'a hamd etme sözü olarak "Elhamdü lillâh" için kısaltılmıș bir șekilde "hamdele" deniyorsa bu da "Bismillâh" kelimesinin kısaltılmışı olarak türetilmiş bir kullanımdır. ${ }^{32}$ Bes-

${ }^{29} \mathrm{Bu}$ bilgiler için bk. Graham, “Basmala”, 210. Bu ansiklopedi maddesinde Graham'ın Râzî̀ye atfedilen Ahkâmül-Besmele isimli eseri kaynakları arasına alması, eserin Râzî̀ye aidiyeti noktasındaki tenkitlerden haberdar olmadığı șeklinde yorumlanabilir.

${ }^{30}$ John R. Bowen, Muslims through Discourse Religion and Ritual in Gayo Society (Princeton: Princeton University Press, 1993), 306-309.

${ }^{31}$ Anlamı ve kökenine dair bir inceleme için mesela bk. Mekkî b. Ebî Tâlib el-Kaysî, el-Keșf 'an vücûhi'lkirâ'âti's-seb', 14

32 Ebû Şâme el-Makdisî, İbrâzü'l-Me'ânî min Hırzi'l-Emânî, 64. Besmele'nin manaları üzerine kisa bir eser kaleme almıș olan lügat, nahv ve tefsir âlimi İbrahim İbnü's-Serî ez-Zeccâc (ö. 311), manası, kökeni, iştikâkı, irabı ve tertibi gibi konularda 80 soru olduğunu söyler. Bunlardan 40'الله lafzı ile 20'si de الرحمن الرحيم isimleri ile ilgilidir. Bu sorulardan bazıları şunlardır: "Bâ" niçin harf-i cer olarak isimlendirilmiştir? Cümledeki konumu nedir? İştikâkı, ismi, vezni nedir? "Elif” niçin hazfedilmiş "sin" niçin sakin kılınmıștır? "Allah" lafzı isim midir sıfat mıdır, iștikâkı var mıdır, varsa 
mele bugün de kullanılan şeklini alıncaya kadar bazı form değişiklikleri geçirmiştir.

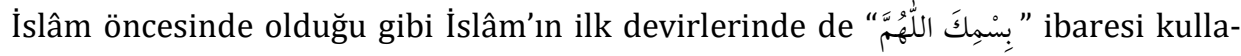

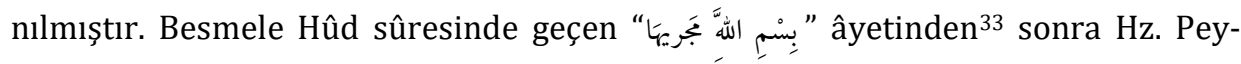
gamber'in emriyle “" şeklinde yazılıp söylenmiş ve bu şekil besmelenin en kısa ifadesi olarak günümüze kadar ulaşan geniş bir kullanıma sahip olmuştur. ${ }^{34}$

Oryantalist metinlerde de "besmele"nin kavramsallaştırılmasında, esasında klasik Arapçada aynen "tesbîh", "tekbîr", "tahmîd", "tehlîl” ve "teavvud"da olduğu gibi fiilin mastarından oluşturulan ismin tercih edildiği belirtilir. Bu manada besmele, "bismillah"ın sessiz ilk dört harfinin kullanılması ile oluşturulmuştur ve alışıldık olmayan bir isimlendirme şeklidir. Besmeleyi ve bununla ilişkili fiil biçimlerini türetmek için bu kök kullanılmıştır. Bu şekilde kullanıldığında anlam "besmeleyi okumak" şekline girmektedir. "Tahmîd" yerine "hamdele" denilebiliyor olması, gerektiğinde birden fazla sessiz harfin kullanımı ile aynı işlemin gerçekleştirilebildiğini göstermektedir. ${ }^{35}$

\subsection{Besmelenin Kişi ve Toplum İçin Anlamı}

Onun diğer Kur'ânî yemin şekilleri gibi olmaktan ziyade İslâm geleneğinde esasında "billâh" yani "Allah ile" anlamında bir dua olarak tercüme edildiği de görülmektedir. Buradan yola çlkarak besmelenin, bir dünya tasavvuruna yönelmiş bir dünya görüşünün içerisine sığdırıldığı bir yol haritasıdır denebilir. ${ }^{36} \mathrm{Bu}$ hassa-

nedir, ona "elif" ve "lam" niçin dâhil olmuștur? "Rahmân ve Rahîm" isim midir sıfat mıdır, iștkâkı var mıdır varsa nedir? vb. 80 soru sorulup cevapları verilmiştir. Değerlendirmeler için bk. İbrahim İbnü's-Serî ez-Zeccâc, el-İbânetü ve't-Tefhîmü 'an Me'ânî bismillâhirrahmânirrahîm, thk. Abdülfettâh es-Seyyid Selîm (Ammân: The Prince Ghazi Trust for Qur'ānic Thought), 55-59.

${ }^{33}$ Hûd 11/41.

${ }_{34} \mathrm{Bu}$ bilgileri ve besmelenin hem söyleniş anlamında hem de hat noktasında geçirdiği aşamaları görmek için bk. Mustafa Uğur Derman - Mustafa İsmet Uzun, "Besmele", Türkiye Diyanet Vakfi İslam Ansiklopedisi (İstanbul: TDV Yayınları, 1992), 5/532-537. Burada şu bilgiler de verilmektedir: "Neml

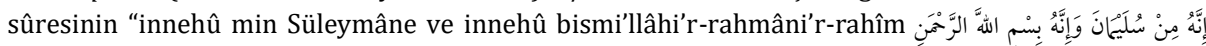

"27/30) âyetini takiben son şeklini almış, hat sanatının ilerlemesiyle bilhassa istifli yazılarda "innehû min Süleymâne ve innehû" ibaresi de besmelenin yanında yazılmıştır. Besmelenin baş tarafına istiâze "eûzü billâhi mineşşeytânirracîm أعوذ باله من الشيطان الرجيم" cümlesinin yazılması da bir âdettir ve örnekleri de az değildir. Bazen da besmelenin sonuna "ve bihî nestaîn وبه نستعين "veya "ve bihi'l-avn وبه العون" ibaresi ilâve edilmiștir".

35 Bu görüşler için bk. John A. Haywood - Halil M. Nahmad, A New Arabic Grammar of the Written Language (London: Lund Humphries, 1965), 263.

${ }^{36}$ Sufi bir hayat açısından besmelenin anlamına dair bir yaklaşım için bk. Titus Burckhardt, Introduction to Sufi Doctrine, Indiana: World Wisdom, 2008, 36. Burada Hz. Ali'den ö. (40/661) besmelenin hüviyetinin ilk harf "bâ" da ortaya çıktığı ve onun altındaki noktanın da tevhîdi remz ettiği nakledilir. İslâm ve Bahâî inancı üzerine kaleme aldığı eserinde Momen, Taberî’den nakledilen bir haberle bu inancın kendisine dayanak bulduğunu söyler. Rasûlullah haber vermiștir: Hz. Meryem, Hz. İsa'yı eğitimi için bir hocaya getirmiş. Hoca ondan "bism" yazmasını istemiş. Hz. İsa bunun ne anlama geldiğini sorunca hoca bilmediğini söylemiş. Bunun üzerine Hz. İsa; "Bâ, Allah'ın yüceliğidir (Baha'u'llah-the glory of Allah); "Sîn", O'nun nûru'dur (His Sana'); “Mîm”, O'nun mülküdür (His Mamlakah)" şeklinde söylemiştir. Bu alıntı için bk. Moojan Momen, Islam and the Bahá'i Faith 
siyeti, Kur'ân harflerini öğrenecek bir çocuğun, eğitiminin başlangıcında yapılan seremoniye "bed-i besmele" denmesinde görmek mümkündür. ${ }^{37}$ Klasik İslâmi anlayıșta yer bulduğu șekli ile esasında besmeleden önce isti'âze'nin şart oluşu, İslam şahsiyetinin önceliklerini gösteren hususlar olarak görmek mümkündür. ${ }^{38}$ Allah'ın herşeyden önce kendi isimlerini peygamberine öğretmiş olması Taberîye ö. (310/923) göre bütün işlerden önce Allah'ın geldiğini ona göstermek içindir. ${ }^{39}$ Kur'ân tilavetinin besmele ile başlatılması, dört yerde 40 şسْمَ رَبِّكَ şeklinde Allah'ı tesbîh etmenin istenmesi, onüç yerde Allah'ı hatırlamanın (zikr) emredilmesi de bu hassasiyetin ifadeleridir. Taberî, Arapların fiillerden mastar elde etmede farklı yollar kullandıklarını söyleyerek "tesmiye" șeklinde mastarlaşmış olan bu fiilin besmelede "ism" kelimesi ile temsil edildiğini vurgulamaktadır. Ona göre bu, "ben okumaya Allah'ın ismi ile başlıyorum" anlamına gelmektedir. ${ }^{41}$

\section{Ebû Șâme'de Rahmân ve Rahîm Kelimelerinin Anlam Kapsamı}

Besmelenin olușturucu unsurlarından "Rahmân" ve "Rahîm" kelimelerinin Allah'ın birbirine paralel sıfatlarından olduğu söylenmiştir. İngilizce'de "Allah, the Merciful, the Compassionate"42, "the Most Merciful God"43, "the merciful and compassionate God" 44 gibi birbiri yerine kullanılabilecek sifat ve tanımlamalarla karşılanmıştır. İslâmi kaynaklar bu iki kelimenin aynı kökten türemiş iki kelime olduğunu belirtirler. Her ne kadar farklı telaffuzda olsalar da bu, onların farklı mastar yapıları almaları dolayısıyladır. İkisinin de "rahmet" kavramından türemiş olmaları dolayısıyla tekrar edilmelerinin gereksiz olduğu söylenecek olursa, aynı kök'e sahip olsalar da benzerlikleri kadar farklılıkları da olduğu söylenerek bir cevap verilmiştir. Bunlar, birbirini desteklemek üzere getirilmiş kavramlar olarak

(Oxford: George Ronald Publication, 2000), 242. (274. sayfada 330 numaralı dipnotta burada verilen naklin Taberî, İbn Kesîr ve Süyûtî’nin tefsirlerinden yerleri de belirtilmektedir). Zeccâc ö. (311/923), sorular halinde besmele'ye dair yazdığı risâlede Hz. İsa ile alakalı bu rivâyete yer vermektedir. ezZeccâc, el-íbâne, 58-59.

37 İbn Kesîr ö. (774/1373), tefsirinde Kur'ân'ın daha küçükken eğitiminin verilmesini hususi bir bașlık altında incelemiştir. İsmail İbn Ömer İbn Kesîr, Tefsîru'l-Kur'âni'l-'Azîm, thk. Sâmî b. Muhammed esSelâme (Dâru Tayyibe, 1420/1999), 1/74-75.

38 Ebû Ca'fer Muhammed b. Cerîr et-Taberî, Câmi'u'l-Beyân 'an Te'vîli'l-Kur'ân (Tefsîru't-Taberî), thk. Abdullâh b. Abdülmuhsin e't-Türkî, (Kahire: Dâru Hicr li’t-Tıbâ'a ve'n-Neşr, 2008), 1/109. Aynı yerde (Tefsîru'l-İsti'âze) Taberî, Şeytan'ın Arap kelamında cin, ins, hayvan her şeyin azgınına verilen isim olduğunu bildirir.

39 Taberî, Tefsîru't-Taberî, 111. Taberî, İbn Abbâs'tan rivâyet edilen bir sözde onun Cebrâil aleyhisselâm'ın Rasûlullâh'a ilk öğrettiği şeyin ne olduğunu şu şekilde bildiriyor: "Cebrâîl'in Muhammed aleyhisselâm'a ilk şunu indirdi. Geldi ve ‘Ey Muhammed استعيذ بالسميع العليم من الشيطان الرجيم de' dedi. Sonra da 'بسم الله الرحمن الحيم' ded dedi. Cibrîl ona [بَbn Abbâs] der ki: 'Rabbini zikrederek oku, kalk ve Allah'ın zikri ile otur'." Taberî, Tefsîru't-Taberî, 112-114.

40 el-Vâkıa 56/74, 96; el-Hâkka 69/52; el-A'lâ 87/1.

41 Taberî, Tefsîru't-Taberî, 115. "Teklîm” yerine "kelâm”, “i'tâ" yerine "'atâ'” kullanıldı̆̆ı gibi besmelede "tesmiye" yerine "ism" kullanılmıştır.

42 Richard Bell, The Qur'ān, (Edinburgh: Edinburgh University Press, 1939), I/10. Bu sayfa Fâtiha sûresinin başlangıcıdır. Diğer sûreler de aynı tercüme ile başlatılmaktadır.

${ }^{43}$ George Sale, The Koran, 1. Erişim 1 Şubat 2005 http://eaaoaa.com/resources/quran.pdf.

${ }^{44}$ Edward Henry Palmer, The Qur'ān, (Oxford: Clarendon Press, 1880), I/1. 
değerlendirilemez. Klasik kaynaklarda lugavî olarak iki kelimenin de iștikâkı verildikten sonra "Rahmân" kelimesinin üzerine binâ edildiği kök ve mastar açısından "Rahîm" kelimesinden daha kapsamlı olduğu Arap dilinin kuralları ile açıklanır. Rivâyetlere bakıldığında "Rahmân" kavramı dünyada bütün mahlûkatı muhtevi iken "Rahîm" kavramı âhirette Müminlere has olan Allah'ın rahmeti anlamında daha dar bir kapsamdadır. ${ }^{45}$ Rahmân isminin mübâlağa içerdiği Rahîm'in ise binasında bu manaya sahip olmadığını söyleyerek Zemahșerî bu fazlalığı "kelimenin binasındaki ziyâdelik, mana açısından da daha geniş olması manasınadır" fehvasınca değerlendirmiştir. Dolayısıyla Rahmân kelimesinin mana kapsamı Rahîm kelimesinden fazla olmaktadır. ${ }^{46}$

Besmelede ve Fâtiha sûresinde الرحمن الرحيم isimlerinin peş peşe zikredilmiş olmasını Mekkî ve aslında ondan da önce Taberî besmelenin Fâtiha'nın bir âyeti olmadığının delili olarak sunmaktadırlar. Zira onlara göre aynı manayı taşıyan kelimelerin birbiri ardınca konulmuş olması doğru değildir. Kur'ân'da bu şekilde bir kullanım yoktur. Araya bir fasıla girdikten sonra aynı kelimelerin kullanıldı̆̆ı vâkîdir fakat peş peşe getirilmesi söz konusu değildir. Ebû Şâme bu yaklaşımı Mekkî̀nin görüşüne reddiye şeklinde açtığı özel bir bâbda eleştirmektedir. Ona göre Kur'ân'da bu şekilde aynı manayı taşıyan kelime ve hatta cümlelerin birbirine komşu bir şekilde art arda getirildiği çok âyet vardır. ${ }^{47}$ Yine ona göre şayet Mekkî b. Ebî Tâlib ve Taberî'nin iddiaları geçerli kabul edilecek olsa bile besmeledeki الحمد له رب (ile Fâtiha sûresindeki ikinci âyet arasında zaten birinci âyet الرحمن الرحيم vardır. Yani bu şart zaten yerine gelmiştir. Ebû Şâme, Mekkî'nin bu muhtemel itirazın önüne geçmek üzere aslında birinci ve ikinci âyet arasında Kur'ân'da başka yerlerde de sıkça başvurulan bir takdim-te'hîr işlemi gerçekleştiğini ve bu iki âyetin الحمد لله الرحمن الرحيم رب العالمين şeklinde okunması gerektiğini ifade ettiğini belirtir. Ona göre zaten "مَالِكِكِ يَوْم الدّين " ile de mülkün sahibi olma anlamında aynı manayı taşımaktadır. Dolayısı ile takdim ve te’hîr işlemi ile bu intizamsızlıktan da korunulmuş oldu. Kur'ân'da bu şekilde uygulama çoktur. Ebû Şâme, Mekkî'nin bahsettiği türden takdim ve te'hîr işlemine kelâmın muktezası gereği başvurulduğunu ve fakat burada böyle bir ihtiyacın söz konusu olmadığını 'Hocamız' diyerek Ebü'l-Hasan Ali b. Muhammed el-Hemedânînnin ö. (569/1173) tefsirinde bu konuyu ele aldığı yeri zikrederek belirtir. 0, Mekkî̀ye karşı çıkmış ve her bir sıfatın bulunduğu yerde en güzel konumunda olduğunu belirtmiştir. Burada bir takdimte’hîrden bahsetmek söz konusu değildir. Besmelede bulunan Rahmân ve Rahîm

45 Taberî'nin bu meyanda getirdiği bir rivâyette Rasûlullâh: "Meryem oğlu İsa: 'Rahmân, âhiret ve dünyanın Rahmânı; Rahîm ise âhiretin Rahîmidir' buyurmuștur. Dolayısıyla Allah'ın Rahmân olması, yarattı̆̆ı bütün mahlûkatına şâmil iken Rahîm olması sadece Müminlere mahsustur. Taberî, 125-126; ayrıca bk. Süyûtî, ed-Dürru'l-Mensûr, 24. Aynı yerde besmelenin nasıl yazılacağına dair Rasûlullâh'ın öğretileri, direktifleri, besmele ile ișe başlamanın hikmet ve değeri, yine nerede besmele ile başlanamayacağı (şiir yazarken mesela) vb konular işlenmektedir.

46 Zemahșerî, Keșşâf, 26.

47 Mesela bk. ez-Zâriyât 50-51; es-Saff 2-3; el-Hâkka 1-3; el-Kâria 1-3; en-Nûr 58-59; el-Müddessir 1820; en-Nebe' 4-5; et-Tekâsür 3-4; el-İsrâ 93, 94, 95. 
isimleri Allah'ın isimleri ile bir yardım dilenmek anlamında teberrüken getirilmiş iken Fâtiha'nın ikinci âyetinde bulunan bu isimler bütün mahlûkâta şâmil bir şekilde getirilmişlerdir. ${ }^{48}$

\section{Nöldeke'nin Rahmân ve Rahîm Kelimelerine Yaklașımı}

Her ne kadar Müslüman ve gayri Müslim yaklaşımlarda bu iki kavramın birbirinin anlam yakınlığı ile ele alındığı görülmekte ise de aslında bu kavramların birbirine zıt bir anlam çerçevesine sahip olduğu da özellikle vurgulanmıştır. Zaten yukarıda buna dair İslâmi kaynaklardaki yaklaşıma birkaç örnek verilmiştir. Bu iki kavramın Allah'ın ismi/sıfatı olarak besmele dışında Kur'ân'da dört kez daha beraber kullanıldığı görülmektedir. ${ }^{49}$ "Rahmân" kelimesi Kur'ân'da elli yedi âyette marifelik takısı olan ال geçerken "Rahîm" kelimesi çoğunluğu "Ğafûr" ismi

ile beraber seksen bir âyette ve tamamı da nekra bir şekilde kullanılmaktadır. Yine "Rahîm" ismi besmelenin dıșında dört defa "er-Rahmân" ismi ile ve "el-'Azîz", "elĞafûr", "et-Tevvâb" gibi diğer isimlerle beraber toplam otuz iki âyette marifeli bir şekilde "er-Rahîm" olarak geçmektedir.

Nöldeke; İbn Hişâm ö. (218/833) ve Taberî'den delil getirerek "Rahmân" isminin (ki kendisi dipnotta bu ismi açık elif ile şحان, şeklinde yazmaktadır) Mekke-

lilere tamamen yeni olan bir isim ve kullanım olduğunu söyler. Her ne kadar bu isim Araplar için yeni olsa da Hz. Peygamber zamanında yaşamış olan Müseylimetülkezzâb’ın ö. (12/633) kendi Tanrısını bu isimle "Rahmân" olarak tanıttığını belirtir. ${ }^{50}$ Nöldeke, peygamber Müseylime șeklinde yer verdiği bu sahte kişiliğin Güney Arabistanlı rakibi Esved'in kendisini "The Rahmān al-Yaman" olarak tanıtmasına karşılık olarak kendisini "The Rahmān al-Yamāma” şeklinde isimlendirdiğini Taberî, İbn Hişâm, Belâzurî ö. (279/892-93), İbnü'l-Esîr ö. (630/1233) ve Zemahșerî gibi klasik İslâm tarihi kaynaklarına dayanarak verir. ${ }^{51}$ Kur'ânî kelimelerin İslâm öncesi köklerine/asıllarına ve İslâm'ın esasına dair yazdığı eserinde Arthur Jeffery ö. (1959) الرحمن şeklinde marife hali ile Allah'ın ismini alırken "er-

Rahîm" ismine yer vermemiştir. Kur'ân'da altmış beșten fazla geçtiğini söylediği bu kelimenin Allah'ın bir ismi ve nerede ise özel ismi olacak şekilde kullanıldığını belirtir. Nöldeke gibi o da Süyûtî ve Zeccâc'dan aktararak Müberred ö. (286/900) ve

${ }^{48} \mathrm{Bu}$ açıklamalar için bk. Makdisî, Kitâbü'l-Besmele, 259-263.

49 el-Fâtiha 1/3; el-Bakara 2/163; el-Fussilet 41/2; el-Haşr 59/22.

50 Süyûtî bunu Sa'lebî ve Taberânî'den naklen Mekke'de Rasûlullâh'ın besmele’yi açıtan değil de gizli bir șekilde söylemesinin sebebi olarak zikreder. Zira Rasûlullâh "Rahmân" ve "Rahîm" isimleri ile beraber besmele'yi açıktan söylediğinde Mekkeliler Müseylime'nin de ilahını "Rahmân” olarak isimlendiriyor olmasından dolayı 'Muhammed, Yemâme'nin ilahına çağırıyor' diye nümayiş yapmaya başladılar. Bunun üzerine Rasûlullâh besmele'nin açıktan söylenmesini yasakladı ve ölünceye kadar da böyle devam etti. Süyûtî burada besmele'nin namazda cehrî değil de hafi söylenmesi gerektiğine dair farklı rivâyetleri vermektedir. Süyûtî, ed-Dürru'l-Mensûr, 29-30.

${ }^{51}$ Nöldeke vd., The History of the Qur'ān, 91-92, dp. 163/III. Nöldeke, İslâm öncesi Sâbiî kitabelerinde "Rahmân" isminin kullanıldığı altı belgeye sahip olduğumuzu söyler. Ona göre Aramice kullanan erken dönem Hristiyan metinlerde bu kullanım nadir iken Süryanice kullanımına benzer bir șekilde ilk dönem İbranice Talmud'da bu isim çok yaygındır. Yani bu ismin kökeni Süryanice'dir. Nöldeke bu fikrine Süyûtî́nin el-İtkân'da عبراني واصله بالخاء المعجمة demesini delil olarak getirir. 
Sa'leb ö. (291/904) gibi erken dönem İslâm ulemasının bu ismin aslının İbranice olduğunu söylediklerini nakleder. Onun da selefi Nöldeke gibi bu kelimenin Arapça "Rahîm"in de içerisinde olduğu birkaç formu olmakla beraber Arapçaya yabancı bir kelime olduğunu ve İbranice asla sahip olduğunu delillendirmeye çalıştığı görülmektedir. Nöldeke'yi de zikrederek bu kavramın kökenine dair araştırmaların sonucunda Yahudi kaynaklı değil daha ziyade Hristiyan kaynaklı bir kelime gibi görünmesini Müseylime ve Esved örneğini vererek iddia etmektedir. ${ }^{52}$ Nöldeke, kendi tasnifine göre "Rahmân" isminin birinci dönemde yalnızca bir defa kullanılmış iken özellikle ikinci dönemde çok sık kullanıldığını ve üçüncü Medine döneminde ise kullanımının nerede ise tamamen terkedildiğini söyler. Kur'ân âyetleri ona göre tamamı ile seslendiği dönem ve kişilerin durumuna göre şekillenmiştir. 0 , kendi sözleri ile Peygamberin bu kullanımı son dönemde terk etmiş olmasının hem Allah hem de Rahmân isminde iki ayrı tanrıya tapıyormuş gibi bir şüpheye yer açmamak olabileceği iddiasında bulunmaktadır. ${ }^{53} \mathrm{Bu}$ ifadelerden, onun, Kur'an'ın ilâhî kelam olmadığını ispata gayret ettiği anlașılmakadır.

\section{Besmelenin Müslümanların Hayatındaki Yeri ve Etkisi}

Müslümanların gündelik hayatta en çok tekrar ettikleri sözlerden biri şüphesiz besmeledir. İslâm öncesinde Araplar arasında bir işe başlarken Lât, Menât, Uzza gibi ilahları adına başlamak adet idi. Bundan dolayı İslâm'ın zuhuru ile muvahhid müminlerin işlerine Allah adına anarak başlamaları hem bir gereklilik hem de bitmeyen bir gelenek ve itiyad oldu. ${ }^{54}$ Câhiliye döneminde Araplar arasında

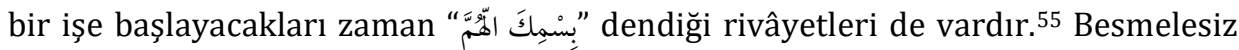

başlayan işin güdük ve bereketsiz olacağı, her işe besmele ile başlayanın cennete ulaşacağı yönündeki rivâyetler ve değerlendirmeler İslâm ulemâsı arasında sıklıkla yapılmıştır. Ebû Şâme Allah'ın, Peygamberine yapacağı her işin önünde kendi ismini zikretmeyi öğreterek onu te'dib ettiğini belirtir. Bundan dolayı her Müslümanın bu sünneti takip etmesi gerekmektedir. Müslümanlar da bütün meselelerinin, eserlerinin, ihtiyaçlarının ve tüm işlerinin evvelinde daima besmele çekmektedirler. Aynı yerde hayvan boğazlarken besmelenin şart kılınmasının bir nevi rahmet sıfatına muğayir olup olmadığı meselesi incelenmiştir. Burada çok ince bir fikir geliştirilerek Allah'ın yarattığı her şeye merhamet etme hususunda herkesten hem daha layık hem de çok daha üstün olduğu vurgulanır. Nihayetinde her canlının bir ölümü olduğu ve bir hayvan için de esasında Allah yolunda kurban edilmesinin en mütesahil ölüm şekli olduğu belirtilir. Aynı zamanda "her acı veren şeyin zımnında -bazen gizli- bir menfaat vardır" genel kaidesi burada da işletilmektedir. Yine Hz. Peygamberin Allah'ın adının anılmadığı yemeğe şeytanın ortak olacağını belirtmesi ve Müslümanları bir şey yerken, içerken besmeleye teşvik etmesi de müşriklerin yapacakları işlerde putlarının adını anmaya bir muhalefete ve hak

\footnotetext{
${ }^{52}$ Arthur Jeffery, The Foreign Vocabulary of The Qur'ān (Baroda: Oriental Institute - Gaekwad's Oriental Series, 1938), 79/140-141.

${ }^{53}$ Nöldeke vd., The History of the Qur'ān, 99.

${ }^{54}$ Zemahșerî, Keșşâf, 25.

55 Ebû Şâme el-Makdisî, Kitâbü'l-Besmele, 131.
} 
üzere davranışı öğretmek olarak takdim edilmiştir. ${ }^{56}$

Sûfî ve Şî̂ gelenekte de besmele özel bir yer tutmuştur. Oryantalist ilginin daha ziyade bu noktada merkezileștiği de söylenebilir. İbn Arabî̀ye göre besmele her sûrenin anahtarıdır. Graham'ın kaydettiği üzere Vladimir Ivanov ö. (1970) tarafından erken dönem İsmailîleri üzerine yapılan çalışmada kozmolojik terimlerle besmelenin şifreli yapısı incelenir. Yine ona göre besmelede yer alan harflerin gizemi de sûfî keşf açısından çok önemlidir. Hatta bütün kutsal kitapların besmelenin başında bulunan "ba" harfinde toplandığı söylenmiştir. Cafer-i Sâdık ve diğer Şiî ulemasına göre de Kur'ân'daki en önemli âyet besmele âyetidir. ${ }^{57}$

\section{Sonuç}

Hakkında müstakil birçok eserin meydana getirilmiş olması besmelenin İslâm ulemâsı ve Müslümanlar arasında tuttuğu yeri göstermektedir. Bu eserlerde konu sadece aktüel yönü ile değil, ilmî, fıkhî ve kavramların kökeni, asıllarının nereye dayandığı gibi teknik yönleri ile de değerlendirilmeye tabi tutulmuştur. Burada özellikle onun Kur'ân'ın bir âyeti olması meselesinin merkezde yer aldığı görülmektedir. Diğer Kur'ânî ve İslâmî ilimlere gösterilen ilgiye nazaran oryantalist yaklaşımda besmele hakkında Nöldeke'nin yaptığı tesbitlerin ötesinde ciddi ve derin araştırma ve değerlendirmelerde bulunulduğunu söylemek zordur. Çağdaş oryantalizmde bu konu üzerinde yetkin çalışmalar yapılmamıştır. Buradan oryantalizmin İslâmi konuları Kur'ân'ı ve İslâm'ı beșer katında olup bitmiş bir hadise olarak görmek şeklindeki ana kavrayış ve hedeflerine götürmede çok faydası olacağının düşünülmemiş olması gösterilebilir.

Kıraat imamlarının besmelenin vücûbiyyeti şeklinde geliştirdikleri kavramsallaştırma fikhî bir neticenin tahsili değil kendi umdeleri içerisinde bir değerlendirmedir. Dolayısıyla kıraat ulemasından vâcib şeklinde bir söz duymak kıraat usulleri ve bahsedilen kıraat imamının tercihi anlamında ele alınması daha uygun görülmektedir. Kur'ân'da açıkça emredilen bir şeklinin varlığı dolayısıyla isti'âzenin vücûbiyyeti hakkında kıraat imamları arasında herhangi bir tartışma söz konusu değilken besmelenin vücûbiyyeti konusunda meydana gelen tartışmaların büyük oranda açık bir emir olmamakla beraber Osman Mushaflarında her sûrenin başında resmedilmiş olmasından kaynaklanmaktadır. Acaba bu bir vücûbiyyet mi ifade etmektedir yoksa sahâbenin bir sünneti olarak mı kabul edilecektir. Bununla beraber besmelenin ne şekilde telaffuz edileceği konusunda vârid olan rivâyetler dolayısıyla ciddi bir ihtilaftan bahsetmek mümkün değildir.

Oryantalistlerin diğer Kur'ânî ilimlerin incelemesinde yaptıkları gibi bu konuda da Müslüman âlimler arasında var olduğu görülen ihtilaflardan yola çıkarak

\footnotetext{
${ }^{56}$ Makdisî, Kitâbü'l-Besmele, 699-700. Burada Ebû Şâme, besmelenin üç yerde vücûbiyetine dair ulemâ arasında ihtilaf olduğunu belirtir. Bunlar da a- Namazda Fâtiha'nın başında okunması b- Abdest alırken söylenmesi ve c- Kurban keserken zikredilmesi. Buralarda fikhen vâcib olması ulemâ tarafından farklı şekillerde değerlendirilmiștir.

${ }^{57} \mathrm{Bu}$ değerlendirmeler ve yine hat sanatı açısından, özellikle de Osmanlı'da Karahisârînnin başını çektiği hatlarda besmelenin konumu açısından bk. Graham, “Basmala”, 211.
} 
konuyu ele aldıkları müşahede edilmektedir. Klasik İslâmi eserlerin bir kısmında zikredilen rivâyetler esas alınmak suretiyle değerlendirmede bulunulmaktadır. Kur'ân'ın otantikliğine dair yapılan üst belirlenimin burada da işletildiği görülmektedir. Oryantalist yaklaşıma göre besmelenin bir benzerine İslâm öncesi kutsal metinlerde rastlamak mümkündür. Bu anlayışa besmelede geçen Allah'ın iki isminin kökenine dair yapılan değerlendirmelerle ulaşmaya çalışılmaktadır. Çağdaş dönem oryantalist yaklaşımda da çokça yer verilen Kur'ân'da bulunan yabancı kelimeler kavramsallaştırmasının burada işletildiği görülmektedir. Bundan dolayı çağdaş dönem oryantalist eserlerde besmele konusunun hususi bir yere sahip olmadığı görülmektedir. Bunun çağdaş dönemde, Nöldeke'nin eserinin ve yaklaşımının yeterli görüldüğü şeklinde bir yargıya ulaşmayı mümkün hale getiren bir tutum olduğu söylenebilir.

Funding / Finansman: This research received no external funding. / Bu araştırma herhangi bir dış fon almamıştır.

Conflicts of Interest / Çıkar Çatışması: The author declare no conflict of interest. / Yazar, herhangi bir çıkar çatışması olmadığını beyan eder.

\section{Kaynakça}

Bowen, John R. Muslims through Discourse Religion and Ritual in Gayo Society. Princeton: Princeton University Press, 1993.

Buhârî, Ebû Abdillâh Muhammed b. İsmail. el-Câmi'u's-Sahîh li'l-Buhârî. I. Kahire/Beyrut: Dâru't-Te'sîl, 1433/2012.

Burckhardt, Titus. Introduction to Sufi Doctrine. Indiana: World Wisdom, 2008.

Bell, Richard. The Qur'ān. Edinburgh: Edinburgh University Press, 1939, I/10.

Derman, Mustafa Uğur, Uzun, Mustafa İsmet. "Besmele". Türkiye Diyanet Vakfi İslâm Ansiklopedisi. 5/532-537. İstanbul: TDV Yayınları, 1992.

Ebû Şâme ed-Dimeșkî el-Makdisî, Abdurrahmân b. İsmail b. İbrahim. Kitâbü'l-Besmele. thk. Adnân b. Abdürrazzâk el-Hamevî el-Ğulebî. Abu Dabi: el-Mecme'u's-Sekâfî, $1425 / 2004$.

Ebû Şâme ed-Dimeșkî el-Makdisî. İbrâzü'l-Me'ânî min Hırzi'l-Emânî. thk. İbrahim Atve 'Avad. Kahire: Dâru'l-Kütübi'l-'İlmiyye.

Enîs, Abdü'l-Hakîm. "Ahkâmü'l-Besmele Leyse Li'l-Fahri'r-Râzî”. Erişim 31 Aralık 2016. https://İslâmsyria.com/site/show library/377.

Graham, William A. "Basmala", ed. Jane Dammen McAuliffe. Encyclopaedia of The Qur'ān. I/207-212, Leiden-Boston-Köln: Brill, 2001.

Hamed, Gânim Kaddûri. el-Müyesser fí 'ilmi't-Tecvîd. Cidde: Merkezü'd-Dirâsâti ve'lMa'lûmâti'l-Kur'âniyye, 1430/2009.

Haywood, John A ve Nahmad, Halil M. A New Arabic Grammar of the Written Language. London: Lund Humphries, 1965.

İbnü'l-Arabî, Ebûbekir Muhammed b. Abdullah. Ahkâmü'l-Kur'ân. Muhammed Abdülkadir Atâ (thr. ve tlk.). II, Beyrut: Dâru'l-Kütübi'l-İlmiyye, 1424/2002.

İbnü'l-Cezerî, Ebü'l-Hayr Şemsüddin Muhammed b. Muhammed. en-Neşr fi'l-kırâ'âti'l-'aşr. nşr. Muhammed Ali ed-Debbâ'. Beyrut: Dâru'l-Kütübi'l-ilmiyye, 1985.

İbn Hacer, Ahmed b. Ali b. Muhammed el-'Askalânî. Fethu'l-Bârî Şerhu Sahîhi'l-Buhârî. I-II, Kahire: Dâru'l-Kütübi's-Selefiyye, 1939/1348.

İbn Kesîr, İsmail b. Ömer. Tefsîru'l-Kur'âni'l-'Azîm. thk. Sâmî b. Muhammed es-Selâme. I, Dâru Tayyibe, 1420/1999. 
Jeffery, Arthur. The Foreign Vocabulary of The Qur'ān. 79 Cilt. Baroda: Oriental Institute (Gaekwad's Oriental Series), 1938.

Kârî, Ali b. Sultan Muhammed. el-Mes'ele fi'l-Besmele. thk. Abdül-Hakîm el-Enîs. Dubâî: Şebeketül-Elûke, 1434/2012.

Kaysî, Mekkî b. Ebî Tâlib. el-Keșf 'an vücûhi'l-kirâ'âti's-seb' ve 'ilelihâ ve hücecihâ, thk. Muhyiddîn Ramazan. Beyrut: Müessesetü'r-Risâle, 1404/1984.

Kurtubî, Ebû Abdillah Muhammed b. Ahmed b. Ebî Bekr. el-Câmi' li-Ahkâmi'l-Kur'ân ve'lMübeyyin limâ Tedammenehû mine's-Sünneti ve Âyi'l-Furkân. thk. Abdullah b. Abdü'lMuhsin et-Türkî. Beyrut: Müessesetü'r-Risâle, 1427/2006.

Momen, Moojan. Islam and the Bahá'i Faith. Oxford: George Ronald Publication, 2000.

Moubarac, Youakim. Les études d'épigraphie sud-sémitique et la naissance de l'Islam: Eléments de bibliographie et lignes de recherches. Paris: Librairie orientaliste Paul Geuthner, 1957.

Nöldeke, Theodor vd.. The History of the Qur'ān. ed. - çev. Wolfgang H. Behn. Leiden-Boston: Brill, 2013.

Palmer, Edward Henry. The Qur'ān. Oxford: Clarendon Press, 1880), I.

Saçaklızâde, Muhammed b. Ebî Bekr el-Mer'aşî. Cühdü'l-Mukıl. thk. Sâlim Kaddûrî el-Hamed. Ammân: Dâru Ammâr, 1429/2008.

Sale, George. The Koran. Erișim 1 Şubat 2005. http://eaaoaa.com/resources/quran.pdf.

Süyûtî, Abdurrahmân b. Ebî Bekr b. Muhammed b. Celâleddîn. el-Mîzânü'l-Ma'dele fî Şe'ni'lBesmele. thk. Abdü'l-Hakîm el-Enîs. Dubâî: Șebeketü'l-Elûke, 1438/2016.

Süyûtî, Abdurrahmân b. Ebî Bekr b. Muhammed b. Celâleddîn. el-Dürru'l-Mensûr fi't-Tefsîri'lMe'sûr. I, Beyrût: Dâru'l-Fikr, 1433/2011.

Taberî, Ebû Ca'fer Muhammed b. Cerîr. Câmi'u'l-Beyân 'an Te'vîli'l-Kur'ân (Tefsîru't-Taberî). thk. Abdullâh b. Abdülmuhsin e't-Türkî. I, Kahire: Dâru Hicr li't-Tıbâ'a ve'n-Neșr, 2008.

Wansbrough, John. Qurānic Studies: Sources and Methods of Scriptural Interpretation. çev. Andrew Rippin. New York: Prometheus Books, 2004.

Zeccâc, İbrahim İbnü's-Seriyye. el-İbânetü ve't-Tefhîmü 'an Me'ânî Bismillâhirrahmânirrahîm. thk. Abdülfettâh es-Seyyid Selîm. Ammân: The Prince Ghazi Trust for Qur'ānic Thought.

Zemahșerî, Ebü'l-Kâsim Cârullâh Mahmûd b. Ömer. Tefsîru'l-Keșşâf. tlk. Halîl Me'mûn Şîhâ. Beyrut: Dâru'l-Ma'rife, 1430/2009. 